\title{
TIMES SERIES ANALYSIS OF ROAD SAFETY TRENDS AT THE REGIONAL LEVEL IN POLAND
}

\section{ANALIZY BEZPIECZEŃSTWA RUCHU DROGOWEGO NA POZIOMIE REGINALNYM W POLSCE Z ZASTOSOWANIEM SZEREGÓW CZASOWYCH}

\author{
Joanna Żukowska \\ Politechnika Gdańska \\ e-mail: joanna.zukowska@wilis.pg.gda.pl
}

\begin{abstract}
The paper presents possibility of applying a structural times series modeling with explanatory and intervention variables as a tool capable for explaining the changes in the monthly number of fatalities and seriously injured in traffic accidents. The analysis covers regional level and takes into consideration traffic accidents data of two regions: Pomorskie and Warmia-Mazury. In addition short-term forecasts for the two regions were developed and verified.
\end{abstract}

Keywords: time-series modeling, road safety, KSI - killed and seriously injured, forecasting

Streszczenie: Artykut prezentuje możliwości zastosowania modeli strukturalnych szeregów czasowych do analizy zmian poziomu bezpieczeństwa ruchu drogowego mierzonego liczba ofiar śmiertelnych $i$ ciężko rannych $w$ wypadkach drogowych. Analiza obejmuje poziom regionalny $i$ wykorzystano do niej dane o zdarzeniach drogowych $z$ dwóch województw: pomorskiego $i$ warmińsko-mazurskiego. Dodatkowo wykonano i zweryfikowano również krótkoterminowe prognozy danych miesięcznych.

Stowa kluczowe: modele szeregów czasowych, bezpieczeństwo ruchu drogowego, KSI - ofiary śmiertelne i ciężko ranne, prognozowanie 
Times series analysis of road safety trends at the regional level in Poland Analizy bezpieczeństwa ruchu drogowego na poziomie reginalnym w Polsce...

\section{Introduction}

Poland's road safety performance has been improving in recent years yet failed to deliver the targets set in its earlier road safety strategy (GAMBIT 2005) [1] and is not on track both to deliver the agreed targets of the current national strategy (NPBRD) [2] as well as EU safety targets (Fig.1). A detailed review of Poland's road safety situation is available in the World Bank's "Road Safety Management Capacity Review" [3] finalized in mid-2013, although since that report progress has been made in a number of areas specially concerning the area of traffic law enforcement.

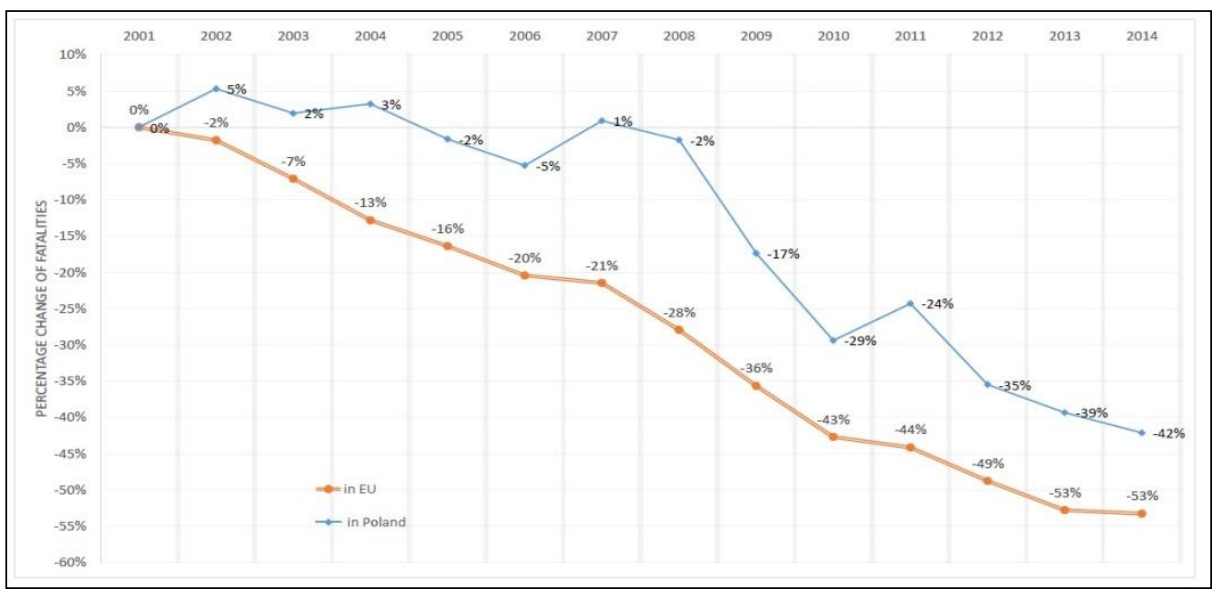

Fig. 1 Percentage change in fatalities in EU and Poland 2001-2014 [4]

While there are many strong elements of road safety data management in Poland, there are still significant weaknesses, gaps, and inefficiencies. One of the fundamental problems for the proper science-based decision-making (crucial for durable road safety improvement) is lack of a stable and reliable safety information system. This applies to both levels of administration: governmental and selfgovernmental [5]. In the result our researchers, specialist and analysts constantly struggle with: inaccuracies of accident data, lack of collection of some key variables, old-fashioned data collection processes, lack of integrated and coordinated data basis ("island" data-basis), limited sharing of data, limited linkages of key data sources, lack of transparency, substantial duplication of effort, finally lack of capacity to employ road safety data to develop policy and programs [6]. However, a number of current developments align to present strong opportunities for advancement. These include increased understanding of the need to improve and co-ordinate road safety data and developments to a number of relevant databases, e.g. the national (POBR) [7] and regional road safety observatories [8]. 
Because road accidents are a complex process the valid data on their number, locations, circumstances, users involved are the basic information that allows evaluating and finding the real causes of accidents and then search for effective ways to improve road safety. The next step are the preventive policies, which should address accidents and should be comprehensive, coordinated and orderly using a consistent set of methods and appropriate technical and organizational means. To achieve it safety information system must work at each level of road administration and methods and technics of road safety trends analysis and prognosis must be developed [9].

The aim of this article is to present one of such analytical method. The idea is to show the possibility of applying a structural times series modeling with explanatory and intervention variables as a tool capable for explaining the changes in the monthly number of fatalities and seriously injured in traffic accidents on the regional level in Poland. The analysis covers regional level and takes into consideration traffic accidents as well as some explanatory data of two regions: Pomorskie and Warmia-Mazury. In addition, short-term forecasts for the two regions are developed and verified.

\section{Road safety trends at regional level in Poland}

Two Polish regions were chosen for the purpose of this analysis: Pomorskie and Warmia-Mazury. Both of them follow the pattern of Polish road safety improvement although their safety results are better than the Polish average (Fig.2).

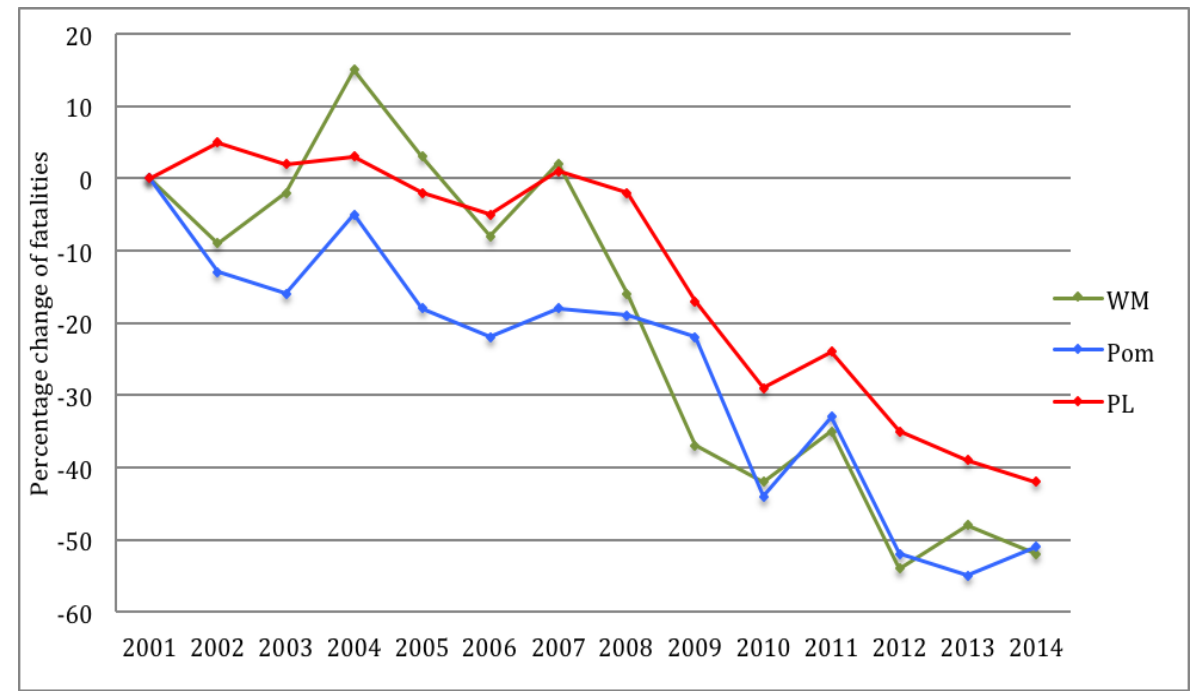

Fig. 2 Percentage change in fatalities in Poland (PL), Pomorskie region (Pom) and Warmia-Mazury region (W-M) 2001-2014 [10] 
Times series analysis of road safety trends at the regional level in Poland Analizy bezpieczeństwa ruchu drogowego na poziomie reginalnym $w$ Polsce...

It is easily seen that the fatality trends were quite constant between 2001 and 2007 while starting from 2007-2008 a period of substantial decrease of the fatalities followed the stabilization. The analysis provided in this document refers to the period of the systematic decrease (2007-2014).

Due to the fact that the analysis is provided for the disaggregated data - monthly numbers for a single region - it was decided to use a sum of fatalities and serious injuries $\left(\mathrm{KSI}^{1}\right.$ ) instead of usually used number of fatalities (to avoid too small numbers). The period of 2007-2014 covered 96 monthly observations both for Pomorskie and Warmia-Mazury regions. The seasonality of the data is very strong (Fig. 3).

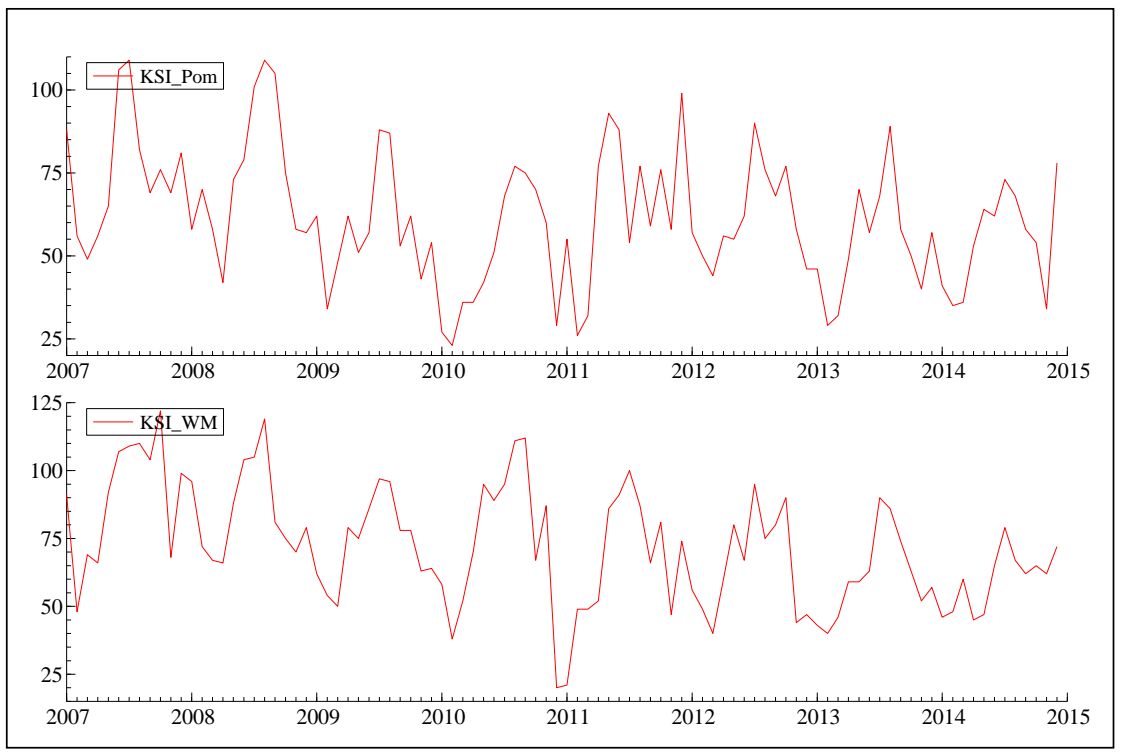

Fig. 3 Monthly number of fatalities and seriously injured (KSI) in Pomorskie (Pom) and Warmia-Mazury (WM) regions 2007-2014 [10]

In the author's previous analysis of road safety trends in Poland - due to the unavailability of traffic data regarded as the best factor expressing the exposure to an accident - it was proved that economic factors might explain some of the changes of the fatality trend. It was also the case in other European countries (e.g. Spain) [11], [12], [13].

\footnotetext{
${ }^{1}$ KSI - killed and seriously injured
} 


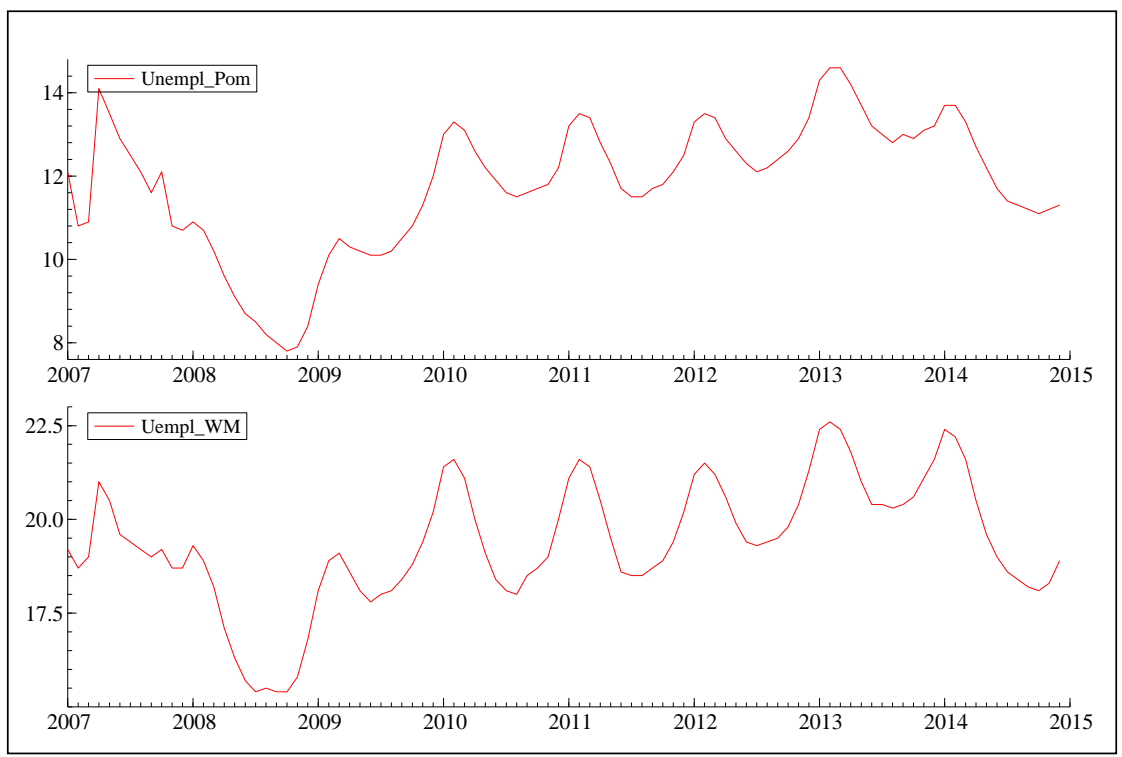

Fig. 4 Monthly unemployment rate (Unempl) in Pomorskie (Pom) and WarmiaMazury (WM) regions 2007-2014 [14]

Thus in the current paper the influence of economy was also taken into consideration. The factor describing the economy condition (which influence society activity and mobility [15], [16] was the unemployment rate ${ }^{2}$.

The methodology used in the paper allows for including the so-called "intervention variables" which are dummy (or indicator) variables used to take account of outlying observations and structural brakes. These data irregularities are usually thought of as arising from a specific event, for example a strike in transport in case of outlier or change in policy in the case of a structural brake. No outliers were found in the case of the analyzed data sets although April 2011 occurred to be the month of a level shift. The explanation of the fact may be the reaction of the society for the change in traffic law raising the speed limits on the express roads and motorways in Poland. The law amendment was introduced on January the 1st 2011 and the real effect on the number of fatalities and seriously injured was visible few months later.

${ }^{2}$ The unemployment rate - the percentage of the number of unemployed in the economically active population 
Times series analysis of road safety trends at the regional level in Poland Analizy bezpieczeństwa ruchu drogowego na poziomie reginalnym w Polsce...

\section{Methodology}

For the purpose of the analysis a structural time-series model of periodic (monthly) discrete time series was chosen [17], [18]. It consists of three basic components: the seasonal component, the trend and irregular interference. It can then be extended according to the needs of the situation: in our case, explanatory variables and interventions are added in order to determine the effect selected factors have on the number of fatalities and seriously injured in the two regions over the analyzed period. Among the potential factors, which are known to impact the road safety level, those selected in this paper include the unemployment rate. Although the technique allows to add any other data e.g. on the weather or road safety measures. The only problem is the availability of the data.

The general formula used for modeling the monthly number of KSI in the case of the current analysis with the structural model was the following:

$$
\begin{array}{ll}
K S I_{t}=\mu_{t}+\gamma_{t}+\beta x_{t}+\sum_{k=1}^{K} \lambda_{k} w_{k t}+\varepsilon_{t} & \varepsilon_{t}=N\left(0, \sigma_{\varepsilon}^{2}\right) \\
\mu_{t}=\mu_{t-1}+\sum_{l=1}^{L} \lambda_{l} w_{l t}+\eta_{t} & \eta_{t}=N\left(0, \sigma_{\eta}^{2}\right) \\
b_{t}=b_{t-1}+\zeta_{t} & \zeta_{t}=N\left(0, \sigma_{\zeta}^{2}\right) \\
\gamma_{t}=-\sum_{j=1}^{s-1} \gamma_{t-j}+\omega_{t} & \omega_{t}=N\left(0, \sigma_{\omega}^{2}\right)
\end{array}
$$

where:

$K S I_{t}$ is the monthly number of fatalities and seriously injured,

$x_{t}$ is the variable measuring the economic factor in the month, with coefficient $\beta$,

$w_{k t}, \mathrm{k}=1, \ldots, \mathrm{K}$, and $w_{l t}, \mathrm{l}=1, \ldots, \mathrm{L}$, are $\mathrm{K}+\mathrm{L}$ intervention variables, with

coefficients $\lambda_{k}$ and $\lambda_{l}$,

$\mu_{t}$ and $b_{t}$ are the level and slope of the local linear trend,

$\gamma_{t}$ is the seasonal component written under a dummy form,

$\varepsilon_{t}, \eta_{t}, \zeta_{t}$ and $\omega_{i t}, \mathrm{i}=1, . ., \mathrm{I}$, are error terms, with variances $\sigma_{\varepsilon}^{2}, \sigma_{\eta}^{2}, \sigma_{\zeta}^{2}$ and

$\sigma_{\omega_{t}}^{2}$ which are not mutually correlated, for $t=1, \ldots, n$.

\section{The results of the analysis}

Initially, four models were estimated for adjusting the number of monthly fatalities and seriously injured in the analyzed regions. All of them used the unemployment rate as an explanatory variable. Finally, only two models (one for Pomorskie and one for Warmia-Mazury) were chosen for further analysis - both of them have the structure of the locally linear model with a linear trend with stochastic level, fixed slope and fixed seasonal component. The results and performance criteria of the models are presented in Tab. 1 
The variances of the disturbances associated to the slope and seasonal component are close to zero which means that both models are locally linear. The correlation to the explanatory variable is in all cases significant. The estimated coefficients are to be interpreted following: an increase of 1 point in the unemployment rate in Pomorskie in the month is associated with a decrease of $2 \%$ in the number of KSI in the month where as an increase of $1 \%$ of the unemployment rate in WarmiaMazury in the month is associated with a decrease of $0,5 \%$ of the number of KSI in the month. At appears that in Pomorskie region the influence of economical factors on traffic is stronger that in Warmia-Mazury region although both results are within the range of results that have been obtained in other countries.

Finally, one intervention was analyzed - level shift in April 2011. The break in the level for Pomorskie region resulted in the increase of the trend by $25 \%$ from April 2011 onwards. This is quite huge shift and may be related to the fact that traffic law on speed limits was changed at that moment. The change influenced the road users and the level of the trend has shifted: an uncontrolled message was given to the society regarding new traffic rules (the tolerance to drive faster on motorways and express roads from 1st January 2011 was in fact anticipated by road users on all the interurban network). The level shift for Warmia-Mazury series was less "spectacular" although 6\% of increase means that also Warmia-Mazury was affected by the change in traffic law.

Table 1. Results and performance criteria of the models fitted on the number of fatalities and seriously injured in Pomorskie and Warmia-Mazury regions period January 2011-December 2014

\begin{tabular}{rrr}
\hline Parameters & Pomorskie & Warmia-Mazury \\
\hline$\sigma_{\varepsilon}^{2}$ & 0.246067 & 0.428859 \\
$\sigma_{\eta}^{2}$ & 0 & 0 \\
$\sigma_{\zeta}^{2}$ & 0 & 0 \\
$\sigma_{\omega_{u}}^{2}$ & 161.547 & 166.639 \\
\hline$\mu_{T}$ & $47.35049[0.00277]$ & $59.76508[0.02112]$ \\
$b_{T}$ & $-0.56385[0.0000]$ & $-0.43547[0.00063]$ \\
\hline Seasonal chi2 & 76.47657 & 81.97452 \\
test & {$[0.00000]$} & {$[0.00000]$} \\
\hline Unempl & $\mathbf{- 2 . 0 2 7 4 1}$ & $\mathbf{- 0 . 5 2 4 2 3}$ \\
t-value & $-1.80478[0.07483]$ & $-0.42762[0.67006]$ \\
shift_4.2011 & $\mathbf{2 5 . 9 7 6 4 9}$ & $\mathbf{5 . 9 6 5 5 6}$ \\
t-value & $4.63332[0.00001]$ & $1.01993[0.31080]$ \\
\hline$A I C$ & 5.29 & 5.3328 \\
$B I C$ & 5.7174 & 5.7602 \\
\hline
\end{tabular}

For each model, are given:

- the estimated variances of the level, slope, seasonal component and residue,

- the estimated level and slope at the end of the period (12.2014),

- the coefficients of the explanatory and intervention variables (in bold), the value of the T-test and the related Probability (in italics),

- the performance criteria : Akaike Information Criteria (AIC), Bayesian Schwartz (BIC) 
Times series analysis of road safety trends at the regional level in Poland Analizy bezpieczeństwa ruchu drogowego na poziomie reginalnym w Polsce...

In consideration of the performance criteria, both models are valid from a statistical point of view.

\section{Prognosis}

One of a crucial motivations and goals of road safety modeling is getting knowledge on future trends development. Structural time series analysis gives the opportunity to achieve the short-term prognosis of the analyzed variables.

For the purpose of the current article a short-term prognosis of KSI development in Pomorskie and Warmia-Mazury was performed under the assumption of fixed unemployment rate within the analyzed period. For Pomorskie region the rate was $11,3 \%$ and for Warmia-Mazury - 18,9\%.

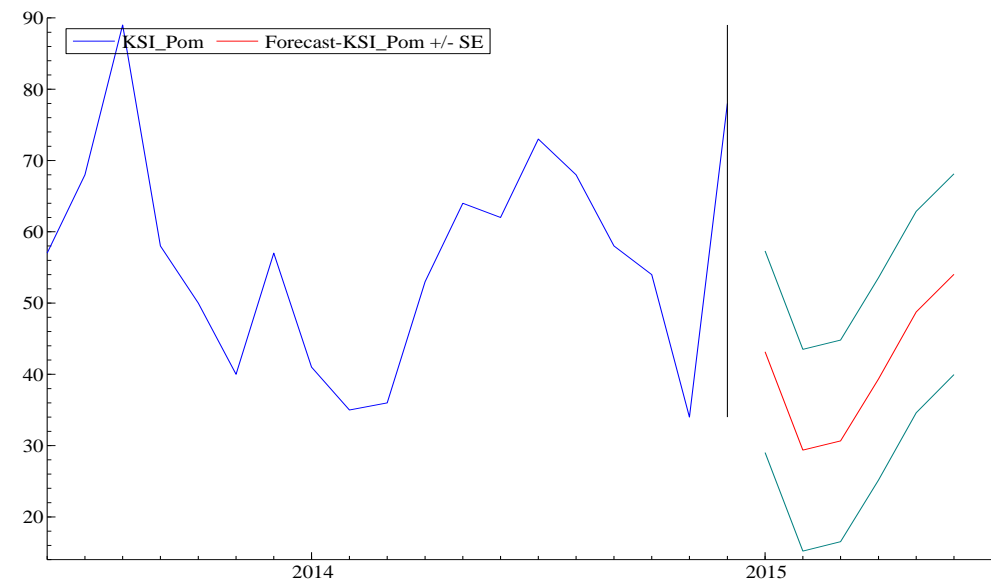

Fig. 5 Forecasts of KSI for Pomorskie (Pom) region (January-June 2015)

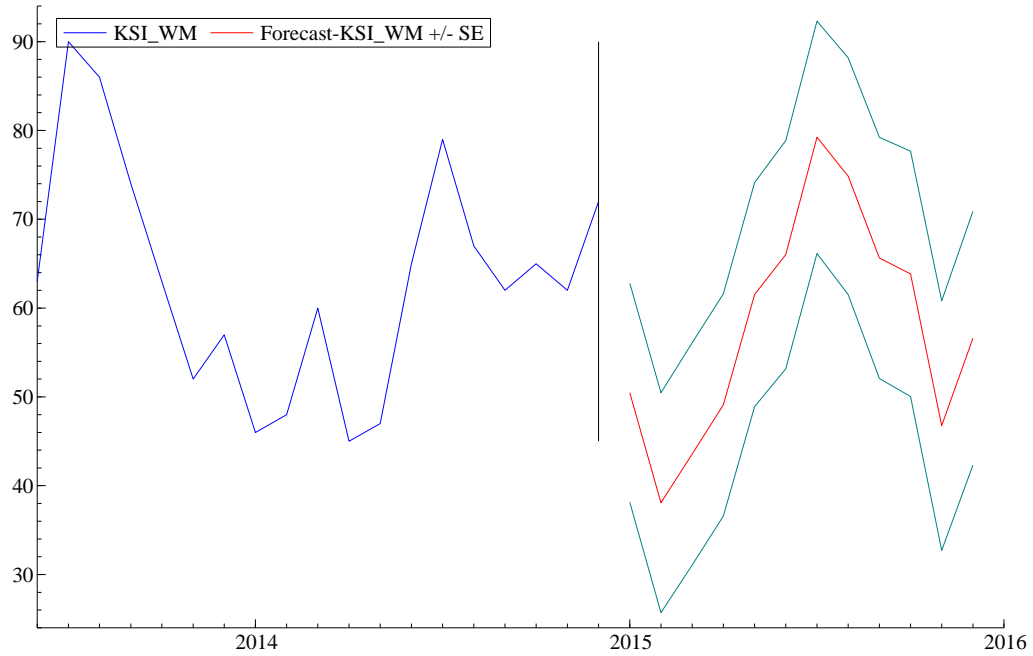

Fig. 6 Forecasts of KSI for Warmia-Mazury (WM) region (January-June 2015) 
Structural time series models (1) were used to develop the forecasts of KSI and the graphical results are presented in the above figures: for Pomorskie (Fig. 4) and Warmia-Mazury (Fig. 5). The results achieved were compared with the real (Observed KSI) values for January-June 2015 and presented in Tab. 2.

Table 2. Forecasts of the number of fatalities and seriously injured (KSI) in Pomorskie and Warmia-Mazury regions - 6 months of 2015

\begin{tabular}{lcccccc}
\hline Forecast & \multicolumn{3}{c}{ Pomorskie } & \multicolumn{3}{c}{ Warmia-Mazury } \\
\hline & \multirow{2}{*}{ KSI } & $\begin{array}{c}\text { Stand. } \\
\text { Err }\end{array}$ & $\begin{array}{c}\text { Obs. } \\
\text { KSI }\end{array}$ & \multirow{2}{*}{ KSI } & Stand. Err & $\begin{array}{c}\text { Obs. } \\
\text { KSI }\end{array}$ \\
\hline Jan 2015 & 43,1584 & 14,137 & 59 & 41,2621 & 14,5943 & 40 \\
\hline Feb 2015 & 29,3594 & 14,155 & 31 & 31,9461 & 14,6451 & 31 \\
\hline Mar 2015 & 30,6566 & 14,1433 & 36 & 36,19 & 14,5872 & 46 \\
\hline Apr 2015 & 39,3589 & 14,1953 & 52 & 43,1888 & 14,5275 & 42 \\
\hline May 2015 & 48,7472 & 14,1288 & 54 & 58,414 & 14,3994 & 52 \\
\hline June 2015 & 54,0359 & 14,0798 & 53 & 64,3298 & 14,3411 & 56 \\
\hline
\end{tabular}

Almost all KSI values achieved within the prognosis appeared to be satisfactory (within the boundaries of 2 standard errors). The exception was the value for January 2015 in Pomorskie region, which slightly exceeded the boundary. This allows assuming that models achieved are correct and may be used for practical purposes (forecasting).

\section{Conclusions}

The results of road safety modeling at the regional level in Poland achieved within current analysis are comparable with the results already obtained within the same approach on the country level in Poland [19], [20]. Also in France in particular, similar results were found as regards the relation between the number of fatalities and the unemployment rate [12]. The results confirm that a structural times series model with explanatory and intervention variables is an appropriate tool for both explaining the changes in the monthly number of fatalities and seriously injured at the regional level in Poland and forecasting the future values and may start to be used by practitioners monitoring road safety trends at the regional level in Poland. Road safety management system in Poland is under continuous development both within the institutional and operational areas. There is lack of tools supporting the operational level, mainly within the regional and local administration. At the same time, implementation process of the new National Road Safety Program 2013-2020 and the regional and local programs need to be monitored and its effects evaluated. Thus modeling techniques and tools must be available and their capacity for the national and regional analysis properly understood. This is the direction that 
Times series analysis of road safety trends at the regional level in Poland Analizy bezpieczeństwa ruchu drogowego na poziomie reginalnym w Polsce...

researchers involved in road safety analysis should follow in the near future to bring the new solutions for the practitioners and decision-makers [5], [21].

The analysis performed in this paper will be continued covering data from all Polish regions to form groups of regions with similar characteristics as regards their economic conditions and fatality/serious injuries trends.

\section{References}

[1] GAMBIT 2005. National Road Safety Program. National Road Safety Council, Warsaw, 2005

[2] NPBRD 2013-2010. National Road Safety Program. National Road Safety Council, Warsaw, 2013

[3] Job, S., McMahon, K., Czapski, R. \& Giemza, J. Country Report on Poland Road Safety Management Capacity Review. Global Road Safety Facility. World Bank, Warsaw, 2013

[4] Report on Institutional Structure for Road Safety Management in Poland (Draft) Global Road Safety Facility. World Bank, Warsaw, 2015

[5] Zukowska, J., Innowacyjne narzędzia zarządzania bezpieczeństwem transportu drogowego na poziomie regionalnym. Autobusy. Technika, Eksploatacja, Systemy Transportowe, 14 (3), 2293-2303 (2013)

[6] Job, S., Czapski, R., Zukowska, J., Giemza, J. Report on Road Safety Information Systems Development for Poland for Poland. Diagnosis and High Level Action Plan. Global Road Safety Facility. World Bank, Warsaw, 2015

[7] Zielińska, A., Buttler, I. Koncepcja baz danych o bezpieczeństwie ruchu drogowego jako elementu Polskiego Obserwatorium BRD. Praca wykonana na zlecenie Ministerstwa Transportu i Budownictwa. Umowa nr TDR/29/2005 $\mathrm{z}$ dnia 18 listopada $2005 \mathrm{r}$.

[8] Żukowska J., Krystek R.: The role of observatories in the integrated transport safety systems. Scientific Journals Maritime University of Szczecin. - 2012, 32(104) z. 2 s. 191-195

[9] Hauer, E. Lessons Learned from Other Countries. White Papers for: "Toward Zero Deaths: A National Strategy on Highway Safety". White Paper No. 9, Vanasse Hangen Brustlin, Inc., July 8 2010, Ontario, Toronto

[10] SEWIK, Polish road accident database. Police Headquarter, Warsaw, 2015

[11] García-Ferrer, A.et al The relationship between road traffic accidents and real economic activity in Spain. Common cycles and health issues. Health Economics, 2007, vol. 16, p. 603-626

[12] Bergel-Hayat, R., Christoforou, Z., Ferriere, S. The impact of the economic crisis on road mortality an exploratory approach for some countries in Europe. ETC, September 30 - October 2, 2013, Frankfurt, Germany, 2013

[13] Jamroz, K. The impact of road network structure and mobility on the national traffic fatality rate. Procedia - Social and Behavioural Sciences, Vol. 54, 4 October 2012, pp. 1370-1377

[14] GUS. Central Statistical Office, Warsaw, 2015 
[15] Brüde, U. What is happening to the number of fatalities in road accidents? A model for forecasts and continuous monitoring of development up to the year 2000. Accident Analysis \& Prevention, 1995, 27, 405-410.

[16] Thorensen, T., Fry, T., Heiman, L., Cameron, M. Linking economic activity, road safety countermeasures and other factors with Victorian road toll. Report No. 29, 1992, Monash University Accident Research Centre, Clyton, Victoria

[17] Commandeur, J.J.F. and Koopman, S.J. An introduction to state space time series analysis. Oxford: Oxford University Press, 2007

[18] Zukowska, J. (2012). Road safety analysis in Poland using time-series modelling techniques. Journal of Polish Safety and Reliability Association Summer Safety and Reliability Seminars, Volume 3, Number1-2, 2012

[19] Bergel-Hayat R., Żukowska J. Structural time series modelling of the number of road fatalities in Poland in relation with economic factors. TRA 5th conference, Paris, 14-17 April 2014

[20] Bergel-Hayat R., Żukowska J. Road safety trends at national level in Europe: a review of time-series analysis performed during the period 2000-12. Transport Reviews: A Transnational Transdisciplinary Journal, 42015 http://dx.doi.org/10.1080/01441647.2015.1030005

[21] Wachnicka, J. Modeling selected road safety measures at the regional level in Europe. Journal of Polish Safety and Reliability Association. Summer Safety and Reliability Seminars, Volume 3, Number 2, 2012

Dr. Joanna Żukowska - researcher and scientist at the Department of Highway Engineering Gdansk University of Technology. Teaches transport safety, road safety and traffic engineering. Author of numerous publications in Poland and abroad on road safety modelling and programming. Co-author of national and regional road safety programes. The main author of the Warmia-Mazury Road Safety Observatory. 
Times series analysis of road safety trends at the regional level in Poland Analizy bezpieczeństwa ruchu drogowego na poziomie reginalnym w Polsce... 